\title{
Hatásköri problémák az Egyesült Királyság kilépése esetén ${ }^{1}$
}

\author{
Competence Issues Concerning \\ the Withdrawal of the United Kingdom
}

\begin{abstract}
A Brexit az uniós jog esetén számos területen okoz változást és jár kihívásokkal. Nem sok szó esik azonban a hatáskör-kiterjesztéshez kapcsolódó esetleges kérdésekröl. A tanulmány célja, hogy egy nemzetközi politikaelméleti-jogi elméleti háttérböl kiindulva pillantást vessen a Brexit folyamatára. Ez három fö pont szemügyre vételét jelenti: a kilépési megállapodást, a megállapodás nélküli kilépésre vonatkozó intézkedéscsomagot és a jövőbeli kapcsolatrendszerre vonatkozó dokumentumokat, úgymint a kilépési megállapodáshoz csatolt politikai nyilatkozatot, valamint a tárgyalási mandátumot. Cél a problémakör felvázolása és némiképpen kontextusba helyezése.
\end{abstract}

Kulcsszavak: Brexit, hatáskörök, jövőbeli kapcsolatrendszer, no-deal, nemzetközi politikaelmélet

The phenomenon of Brexit means changes and generates challenges for the law of the European Union. There is, however, not so much talk about the question of competence extension. The aim of this paper is to have a look at the process from an international political theoretical and legal theoretical perspective. This means the examination of three parts: the withdrawal agreement, the no-deal package and the documents related to the future relationship between the European Union and the United Kingdom, namely the political declaration and the negotiating mandate. The aim of the study is to outline the problem and contextualise it to some extent.

Keywords: Brexit, competences, future relationship, no-deal, international political theory

Budai Péter az ELTE ÁJK Állam- és Jogtudományi Doktori Iskolájának (Nemzetközi Jogi Tanszék) másodéves hallgatója, az Igazságügyi Minisztérium európai uniós jogi szakértője. E-mail: peter. budai2@im.gov.hu. A tanulmányban megfogalmazott vélemény kizárólag a szerző saját álláspontját tükrözi.

1 A tanulmány Az Innovációs és Technológiai Minisztérium ÚNKP-19-3 kódszámú Új Nemzeti Kiválóság

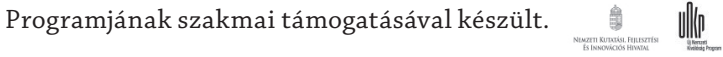




\section{Bevezetés}

Az Egyesült Királyság kilépése egy olyan kihívás, amellyel az Európai Unió eddig nem szembesült, mivel még egyetlen tagállam sem akarta elhagyni az integrációt. Mivel ennek gyakorlata sem volt, így egyértelmű, hogy ez nem ment zökkenőmentesen. Jól látható, hogy az unió számára ez egy olyan kihívás, amely jelentős befolyással lehet arra, hogy hogyan halad tovább majd az integráció folyamata. Ahogy minden ilyen folyamat, ez az uniós jog szintjén is ellentmondásos és homályos. Hiába vált jogilag lehetségessé az unióból való kilépés a lisszaboni reformokkal, a jogi háttér és az eljárások hézagos volta, valamint a szándék visszavonhatóságának kérdése újabb és újabb megoldandó jogi problémák elé állította az EU-t. Nem is olyan meglepő, hogy a kérdéskör egy-egy vonulata a hatáskör-kiterjesztés kérdésével is összefüggésbe hozható. Röviden összefoglalva a hatáskör-kiterjesztés vagy competence creep az Európai Unió részéről egy olyan eszköz, amely alapján olyan esetekben alkot jogot vagy jár el, amelyre nincs kifejezett felhatalmazása. Úgy vélem, az ehhez kapcsolódó ellentmondásosságokat érdemes azonosítani és kontextusba helyezni. Ebből következően a tanulmány célja, hogy ezeket a kihívásokat azonosítsa, és értelmezési keretet biztosítson neki.

Ehhez nemzetközi politikaelméleti és jogi elméleti hátteret egyaránt használok, amelynek oka a probléma komplexitása. Ebből következően az előbbi részéről az angol iskolát, míg a jogelmélet részéről Guy Fiti Sinclair munkásságát vizsgálom. Ezt az Európai Unióval és a hatáskör-kiterjesztéssel kapcsolom össze, mivel úgy vélem, hogy az integrációt vizsgáló elméletek, tehát az intergovernmentalizmus, a neofunkcionalizmus és a multilaterális kormányzás az utóbbira nem ad kielégítő és meggyőző magyarázatot. Ezt követően térek ki az Egyesült Királyság kilépésének vizsgálatára. A Brexit folyamata sokrétű, ugyanakkor bizonyos tekintetben felfedezetlen, és kontextusba helyezése sem könnyű. A célom az, hogy egy lehetséges magyarázatot adjak vele a hatáskörrel kapcsolatos ellentmondásosságokra. Ehhez három fő részt különítek el: a kilépési megállapodásra, a no-deal csomagra, illetve a jövőbeli kapcsolatrendszerre vonatkozó részeket.

Mivel a cikk elméleti hátteret használ fel, amely azonban később az uniós jogot és a Brexit folyamatát veszi górcső alá, így a megközelítés is kettős. Az elméleti háttérhez az angol iskola szerzőinek műveit és nemzetközi jogelméleti műveket, főleg Guy Fiti Sinclair munkáját vizsgálom. Az uniós jogi kérdések esetén az uniós jog forrásaira (kiemelten a kilépési megállapodásra, a no-deal csomagra, a politikai nyilatkozatra és a tárgyalási mandátumra) és az azokat magyarázó szerzők műveire hagyatkozom, hogy érzékeltessem az elmélet és a „megvalósítás” összefüggéseit. A cikk funkciója nem a kérdések megválaszolása, sokkal inkább ezek azonosítása. 


\section{Egy lehetséges vizsgálati keret: a nemzetközi politikaelmélet és a jog kapcsolata}

\section{Nemzetközi politikaelmélet: az angol iskola}

A hidegháború időszakában a nukleáris fegyverkezésre, a szuperhatalmak létére, a bipoláris nemzetközi rendre, a gazdasági integrációk erősödésére, valamint a különböző interdependenciák jelenségeire a neorealizmus, valamint a neoliberalizmus igyekezett kielégítő magyarázattal szolgálni. Mivel azonban egyik iskola sem volt képes valamenynyi folyamatot kellő alapossággal értékelni, a nemzetközi politikaelmélet tudományterületén belül felerősödtek a kritikus hangok. (Sterling-Folker, 2013:114-118) Ennek egyik következménye az úgynevezett angol iskola létrejötte, amely azon túl, hogy hangsúlyozta a neorealizmus és a neoliberalizmus hiányosságait, igyekezett azok vívmányait egységes elméleti keretbe foglalni. Ebből következően hangsúlyozta az önérdekkövetés és az anarchia fontosságát a nemzetközi kapcsolatokban, ugyanakkor elismerte a nemzetközi jog és a nemzetközi szervezetek jelentőségét is. (Bull-Watson, 1984:452) $\mathrm{Az}$ angol iskola a nemzetközi kapcsolatok megértéséhez három hagyományt alkalmaz: a realista (hobbesi), a racionális (grotiusi) és a forradalmi/univerzalista (kanti) hagyományt. Az irányzat emellett az előbb említett hagyományokat három további koncepcióval azonosítja: a realizmust a nemzetközi rendszerrel, a racionalizmust a nemzetközi társadalommal, valamint az univerzalizmust a világtársadalommal. (Scheele, 2013:2)

$\mathrm{Az}$ angol iskola egyik alapítóatyja, Hedley Bull úgy határozta meg a nemzetközi rendszert (hobbesi hagyomány), mint egy olyan, két vagy több államból álló rendszert, amelyben az egyes államok rendszeresen érintkeznek egymással, hatást gyakorolva ezzel egymás viselkedésére és döntéseire. (Bull, 2012:9) Ebből következően a nemzetközi rendszerben az államok közötti hatalompolitikai viszonyok állnak a középpontban, illetve az azokból következő egyes szereplők érdekei. (Buzan, 2004:7) A nemzetközi rendszert a realizmus logikája alapján az anarchizmus határozza meg, amelyben az államok elsődleges célja a túlélés, ezen túl azonban léteznek a szereplők által meghatározott más egyéni érdekek is. (Barkin, 2003:328)

A nemzetközi társadalom (grotiusi hagyomány) a nemzetközi rendszerrel szemben nagyobb hangsúlyt fektet az államok közös érdekeinek intézményesítésére, az államok által elismert közös normákra, szabályokra és intézményekre. A nemzetközi társadalom tagjai már elfogadják a tényt, hogy vannak olyan közös érdekek, amelyek alapján bizonyos esetekben közös fellépésre is hajlandóak. (Bull, 2012:13) Ennek oka, hogy kialakult az államoknak az egymástól való függése föleg a gazdasági kapcsolatokban. Mivel azonban e közös érdekek létezése mellett a nemzetközi kapcsolatok anarchikus természete továbbra is kihat az államokra, Bull ezt a sajátos anomáliát anarchikus társadalomnak nevezi. (Bull, 2012:44-49) A nemzetközi társadalomban a szuverenitás komoly szerepet kap, mivel ez garantálja annak fennmaradását, ugyanakkor a szereplők által elismert szabályok korlátozzák a szuverenitásukat egyes közös érdekek megvalósításáért. (Scheele, 2013:2) 
A harmadik, a világtársadalom (kanti hagyomány) az egyént, a nem állami szereplőket, de akár a világ népességét is vizsgálja és beleilleszti a nemzetközi kapcsolatok fókuszába, amivel az angol iskola a transznacionális elemet is bevonja elméleti keretébe. (Buzan, 2004:7-8) Remek példa ennek fontosságára a keresztény egyháznak az egyes korokban betöltött szerepére vonatkozó vizsgálat. (Dunne, 2013:140) Ezen elem fontossága főleg amiatt indokolt, mivel a nemzetközi kapcsolatokat nem lehet kizárólagosan államközi kapcsolatokként értelmezni. (Bull, 2012:35) Ebből következően hangsúlyozandó az az összefüggés is, hogy a nemzetközi társadalom és a világtársadalom egymással kapcsolatban áll, mivel az utóbbi elősegíti az előbbit újabb és újabb célok kijelölésében. (Buzan, 1993:351)

A nemzetközi társadalom esetén kiemelendő az úgynevezett intézmények megléte, amelyek annak alapjaiként szolgálnak. (Wendt-Duvall, 1989:52-53) Ezek olyan szokások vagy szabályszerúségek, amelyek lehetővé teszik, hogy az államok a nemzetközi társadalmon belül a megfelelő közös célokat kijelöljék és azokra vonatkozóan megfelelő gyakorlatokat vezessenek be. Lényegében az intézmények azok, amelyek megteremtik a keretet az államok közös érdekei számára, és biztosítják a nemzetközi társadalom fennmaradását. (Knudsen, 2019:28) Bull ezek alapján öt ilyen intézményt határozott meg: a nemzetközi jogot, a diplomáciát, a hatalmi egyensúlyt, a nagyhatalmiságot és a háborút. Ezeket a legfőbb intézményből, a szuverenitásból vezette le. (Bull, 2012:68-71) Habár más szerzők később továbbiakat is megkülönböztettek, elmondható, hogy az intézmények jól láthatóan már a vesztfáliai békerendszer előtt kialakultak, a szuverenitással nyerték el azonban jelenlegi helyüket a nemzetközi társadalomban. (Knudsen, 2019:30-33)

Az intézmények sajátos jellemzőkkel rendelkeznek. Először is, interszubjektívek, vagyis az ember (korlátolt) racionalitásából következnek és a közöttük levő interakciókból keletkeznek, amelyek végül a társadalomban, jelen esetben a nemzetközi társadalomban jelennek meg. (Jackson, 2011:126-137) Az intézmények további jellemzője, hogy a nemzetközi társadalom főbb szereplőivel, tehát az államokkal is kölcsönhatásban vannak. Az államok szuverénként a nemzetközi közösség tagjaként a többi szereplővel is kapcsolatot létesítenek és tartanak fenn többek között a diplomácia, a háború és a nemzetközi jog eszközeivel élve. Ezek a cselekvések azok, amelyek a nemzetközi társadalom intézményeit lényegében létrehozzák és „újratermelik”. Ez a kapcsolat ugyanakkor kölcsönös: az államok közötti kapcsolatok az intézmények nélkül nem lennének lehetségesek. Lényegében az államok és az intézmények egymással kölcsönhatásban vannak, egymást legitimálják. (Wendt-Duvall, 1989:53, 58-63)

Az intézmények e különleges kapcsolata azonban nemcsak az államokkal áll fenn. $\mathrm{Az}$ angol iskola egyik úttörője, Buzan már hangsúlyozta az egyes nemzetközi szervezetek fontosságát, illetve az intézmények és a közöttük levő kapcsolatot. Ennek eredményeképpen megkülönböztette az elsődleges intézményeket (vagyis az intézményeket) és a másodlagos intézményeket (vagyis a nemzetközi szervezeteket). (Buzan, 2004:163167) A két csoport között ugyanúgy megfigyelhető egy egymást erősítő kölcsönhatás, mint az államok és a nemzetközi szervezetek között. Az elsődleges intézmények előfeltételei annak, hogy a nemzetközi szervezetek, tehát a másodlagos intézmények egyáltalán létezhessenek. (Knudsen, 2019:41) Például a nagyhatalmiság intézménye szolgál alapul az Egyesült Nemzetek Szervezete Biztonsági Tanácsa (ENSZ BT) számára, mivel 
öt állandó taggal rendelkezik, amelyek a nem állandó tagokkal ellentétben vétójoggal bírnak. A fentebbiek mellett a másodlagos intézmények azok, amelyek visszaigazolják az elsődleges intézmények létezését. Meghatározzák a tagok számára, hogy milyen szabályokat, eljárásokat és gyakorlatokat kövessenek tagságuk során, vagyis körülhatárolják a tagok mozgásterét az adott nemzetközi szervezeten belül. (Navari-Knudsen, 2019:8) Ebből következően azonban ezek a szervezetek túllépnek az egyszerű legitimációs szerepükön, mivel bizonyos mértékig képesek arra, hogy az intézményekre érdemi hatást is gyakoroljanak. Ez nem azt jelenti, hogy alapjaiban meg tudnák azokat változtatni, ugyanakkor képesek arra, hogy azok tartalmát bizonyos mértékig módosítsák. Ez nemcsak a regionális szervezetekre, de az univerzális szervezetekre is igaz. (Knudsen, 2019:42-43)

\section{Jogtudomány: Guy Fiti Sinclair elmélete}

Látható, hogy az angol iskola rámutat a nemzetközi közösség és az azt alkotó egyes szereplők, az államok és a nemzetközi szervezetek közötti összefüggésekre, azonban a nemzetközi jogot érintő egyes részletkérdésekről többnyire nem foglal állást. Ez kifejezetten igaz az olyan jogi kérdésekre, amelyek a nemzetközi szervezetekhez kapcsolódnak. A nemzetközi jogtudomány azonban vizsgálja ezt a kérdéskört is, foglalkozik azok jogi helyzetével, felépítésével, funkcióival és hatásköreivel. Elenyésző azonban az olyan múvek száma, amely ezen szervezetek hatásköreinek bővítését vizsgálja annak teljességében. Az eddigi szerzők többsége nagyobbrészt csupán az egyes tendenciákat és jelenségeket vizsgálta alaposabban, mint amilyen például a beleértett hatáskörök vagy a hatáskörtúllépés esetei. (Schmermers-Blokker, 2011; Sinclair, 2017:7) Kivételt képez ez alól azonban Guy Fiti Sinclair To Reform the World - International Organizations and the Making of Modern States címú müve.

Sinclair elmélete a nemzetközi szervezetek alapító szerződéseiből indul ki. Ezek azok a szerződések, amelyek meghatározzák az egyes szervezetek célját, jogalanyiságát, egyes szerveit, eljárásait és hatásköreit. Sinclair ezzel kapcsolatban felhívja a figyelmet az alapító szerződésben foglalt szabályok sajátos természetére is a hatáskörök bővítése esetén. Hangsúlyozza, hogy idővel az egyes nemzetközi szervezetek újabb és újabb célokat találnak ki, és ehhez megfelelő hatásköröket is alkotnak. Ez nagyon gyakran úgy következik be, hogy a nemzetközi közösség megismerkedik egyes, főleg a civil és az akadémiai szférából származó újabb trendekkel és ideológiákkal. Ebből következően a nemzetközi szervezet mintegy hatáskört kreál a maga számára. Sinclair ezt a jelenséget három szervezeten keresztül elemzi: a Nemzetközi Munkaügyi Szervezet (ILO), az ENSZ békefenntartó missziói és a Világbank példáin keresztül. (Sinclair, 2017)

Sinclair a fentebb ismertetett jelenséget alkotmányos növekedésnek (constitutional growth) nevezi, amelyet Georg Jellinek alkotmányváltozás-elméletéből vezet le. (Sinclair, 2017:18) Jellinek lényegében arra mutat rá, hogy egy állam alkotmányának szövege változatlan maradhat úgy, hogy közben a szabály mögöttes tartalma változik annak újabb értelmezése(i) miatt. (Jellinek, 1906:8) Sinclair szerint a nemzetközi szervezetek esetén is hasonló folyamat játszódik le. Álláspontja szerint a növekedésre irányuló szándék az alapító államok számára nem jelenik meg egyértelműen a nemzetközi 
szervezet megalakulása során, mivel azok alapító szerződéseiben nem található az egyes, később felmerülő ügyekre vonatkozó hatásköri rendelkezés. Ezeket az egyes szervezetek újabb hatáskörökre a kialakított gyakorlatokkal, precedensekkel és a már létező szabályok átértelmezésével érik el úgy, hogy közben az alapító szerződések szövege változatlan marad. (Sinclair, 2017)

Ez a folyamat azonban nemcsak azt eredményezi, hogy az adott szervezet a tagállamaitól hatásköröket vesz el vagy azok számára korlátokat állít fel. Sinclair szerint a nemzetközi szervezet nem csupán a tagállamok által létrehozott olyan formáció, amelyben az államok azért küzdenek, hogy minél több előnyhöz jussanak, hanem hogy azért cserébe minél kevesebb engedményt tegyenek, avagy hatáskört adjanak át. (Sinclair, 2017:284) A szerző szerint a nemzetközi szervezetek növekedését tudatosan úgy alakították ki, hogy a tagállamaiból a nyugati modellhez többé-kevésbé illeszkedő modern államokat hozzon létre. A szerző gyakorlatilag az államot egy olyan úgynevezett szuperstruktúraként határozza meg, amely különböző gyakorlatokon keresztül, egy kulturális folyamat során formálódott és jelenleg is formálódik. (Sinclair, 2017:2, 14) Ez azonban nem csupán korlátozó jellegű volt az államok számára, hanem azoknak egyes esetekben mozgásteret biztosított, ami összességében a modern államiság alapjául szolgált. Ezzel a nemzetközi szervezetek formálták is az államokat, ez pedig sokszor nem lineáris, hanem egymásnak ellentmondó elemeket tartalmazó folyamat. (Sinclair, 2017:15-30) Ebből következően Sinclair számára a jog nem egy egységes konstrukció, sokkal inkább a társadalmi interakciókon keresztül folyamatosan formálódó rendszer, amely a fentebbiek alapján egymással össze nem egyeztethető elemeket is tartalmaz. Ebből következik gyakorlatilag a jog összetett, de ellentmondásos természete is. (Marks, 2003; Sinclair, 2017) A jog egyrészröl lehet hatalmi eszköz, egy eszköz arra, hogy egy összetett problémát megfelelően kezeljen, vagy akár egy olyan elméleti konstrukció, amelyet elméleti szinten tesz magáévá a nemzetközi szervezet, mint amilyen az emberi jogok esete. (Sinclair, 2017:276-292)

\section{A két komponens összefüggései}

Álláspontom szerint Sinclair és az angol iskola gondolatai egymással összeegyeztethetők, így alkalmasak egy megfelelő elméleti keret kialakítására a következő okokból:

Először, az angol iskola fontosnak tartja a nemzetközi jog és a nemzetközi szervezetek vizsgálatát. Amíg a nemzetközi kapcsolatok realizmusa elhanyagolhatónak tartja ezeket a nemzetközi kapcsolatok esetén, addig az angol iskola, átvéve a liberalizmus e jellemzőit, komoly jelentőséget tulajdonít az államok közötti együttműködésnek és az azt lehetővé tevő keretrendszernek. A nemzetközi jogot ezen túl a nemzetközi társadalom alappillérének, elsődleges intézménynek tekinti, amelynek ebből következően a másodlagos intézményekkel különleges, egymást kölcsönösen legitimáló kapcsolata van.

Másodszor, az előbbiből adódóan az angol iskola kifejezetten hangsúlyozza, hogy az elsődleges és a másodlagos intézmények között egy egymást kölcsönösen legitimáló kapcsolat van, ami Sinclair elméletében is előjön. Itt főleg a másodlagos intézmények hatása szorul magyarázatra. Sinclair erre vonatkozóan megjegyzi, hogy a nemzetközi szervezetek tevékenységükkel és hatáskörük bővítésével létrehozzák a modern állam 
koncepcióját. Anélkül, hogy mélyebb vizsgálatot végeznénk, látható, hogy ez komoly változásokat jelent a szuverenitás tekintetében. Mivel a szuverenitás minden elsődleges intézmény alapja, Sinclair lényegében elismeri az angol iskola által felvázolt kapcsolatot.

Harmadszor, Sinclair elismeri a jog többfunkciós létét. Amellett, hogy kiemeli, hogy a jog szabályokat hoz létre egyes kérdéskörökre vonatkozóan, kiemeli annak a hatalommal való kapcsolatát, illetve annak az ideológiai hátterét is. Ezzel lényegében két dolgot hangsúlyoz: egyrészt, hogy a civil és akadémiai szféra/világtársadalom kapcsolatban áll az államok közötti viszonyokkal, és az hat ez utóbbira, másrészről azt, hogy a jog kapcsolatban áll a hatalmi kérdésekkel is. Az angol iskola sajátossága, hogy a nemzetközi kapcsolatokban az egyes jelenségeket igyekszik azok teljes összetettségében vizsgálni. Látható, hogy Sinclair a nemzetközi jogot ezen összetett voltában elemzi.

\section{Az Európai Unió vizsgálhatóságának kérdése}

Sinclair szerint a nemzetközi szervezetek közül nem mindegyik törekszik hatásköreinek bővítésére, vagy ha törekszik is, nem mindegyik sikeres. Példáiban három esetben mutatott rá ilyen tendenciára: az ILO, az ENSZ békefenntartó missziói és a Világbank esetén. Habár ezek univerzális nemzetközi szervezetek, ugyanakkor semmi nem indokolja azt, hogy egyes regionális nemzetközi szervezetekre ne lenne alkalmazható egy ilyen elméleti megközelítés. A kérdés az, hogy vajon az Európai Unió, mint egy igen sajátságos képződmény, mennyiben feleltethető meg egy ilyen keretrendszernek, mivel számos szerző szerint jóval több, mint egy nemzetközi szervezet. Látható azonban, hogy egyes jellemzői alapján (még mindig) nagyban hasonlít azokra.

\section{Az EU vizsgálhatóságának kérdése}

Leggyakrabban úgy határozzák meg az Európai Uniót, mint egy úgynevezett sui generis szereplőt a nemzetközi kapcsolatokban, ezzel azonban nem adnak választ arra a kérdésre, hogy milyen entitásról is van szó. (Ziegler, 2011:268-270) Vannak olyan megközelítések, amelyek az uniót egy sajátos föderális alapokon múködő struktúrának tekintik (Schütze, 2012:77-79), de Bull szerint akár egy olyan „szuperállamként” is felfogható, amely egy sajátos társadalomként funkcionál. (Bull, 2012:256) Más megközelítések a nemzetközi szervezetekhez való hasonlóságát hangsúlyozzák, illetve annak tényét, hogy az EU egy nemzetközi szervezetként indult. (Schütze, 2012:48; Klein, 2018) Megjegyzendő ugyanakkor, hogy még az uniót ilyen szervezetként meghatározó források jelentős része is elismeri, hogy ahhoz egy sajátos, más nemzetközi jogi rezsimeknél sokrétủbb jogrend kapcsolódik. (Odermatt, 2018) Ez utóbbi gondolatiságot talán az a megközelítés fejezi ki leginkább, amely az EU-t egy úgynevezett regionális gazdasági integrációs szervezetnek tekinti, hangsúlyozva ezzel annak sajátos jellegét és a tényt, hogy nem egy egyszerű nemzetközi szervezetről van szó, mivel egy közös piac és egy sajátos elveken működő jogrend is kapcsolódik ahhoz. (Odermatt, 2018:239)

$\mathrm{Az}$ angol iskola szerzői egyetértenek abban, hogy az EU egy olyan regionális szerveződés, amelyhez egy regionális nemzetközi társadalom is tartozik, amelyben a szolidáris 
elem jelentősebb szerepet kap az univerzális nemzetközi társadalom egészéhez képest. (Ahrens, 2019:265-266; Diez-Manners-Whitman, 2011) Ezt támasztja alá az Európai Unióról szóló Szerződés² (a továbbiakban: EUSZ) 2. cikke, amely szerint az EU egésze „az emberi méltóság tiszteletben tartása, a szabadság, a demokrácia, a jogállamiság, valamint az emberi jogok" tiszteletén alapul. Ehhez mintegy hozzátartozik az is, hogy az EU erősíteni kívánja ezt a regionális nemzetközi társadalmat (Ahrens-Diez, 2015), többek között olyan vívmányokkal, mint az uniós polgárság intézménye vagy a szupranacionális intézményi rendszer. (Diez-Whitman, 2002:51) Nem véletlen, hogy az EU hatással van egyébként az elsődleges intézményekre is, csakúgy, mint a nemzetközi szervezetek. (Diez-Manners-Whitman, 2011:123) Erre vonatkozóan megjegyzendő, hogy az európai integráció szinte valamennyi elsődleges intézményt legitimálja magatartásával, ugyanakkor egyes intézményeket újra is értelmez. Elegendő, ha a szuverenitás kérdésére gondolunk, amelyhez az unió hozzákapcsolja a szupranacionális elemet. (Buranelli, 2019:242-243) További példa lehet Diez, Manners és Whitman (2011:123-134) azon elmélete, amely szerint a Bull által felvázolt elsődleges intézményeket az EU valamelyest átértelmezi: többek között a nagyhatalmiság helyett a tagállami koalíciók, míg a nemzetközi jog helyett az uniós jog kap nagyobb szerepet az EU-n belül.

Az EU e sajátosságát a már említettek alapján az uniós jog természete is megerősíti. Az Európai Unió Bíróságának (a továbbiakban: a Bíróság) esetjoga alapján az EU egy új sajátos jogrendet teremt, amely alapján saját intézményekkel rendelkezik, és amely alapján a tagállamok szuverén jogaikat bizonyos mértékig korlátozzák. ${ }^{3} \mathrm{Ez}$ a nemzetközi jogon túlmutató, alkotmányjogi jellemzőket feltételez a Bíróság 1/91. sz. véleménye alapján. Megjegyzendő, hogy az uniós jog egyik eszköze az unió szolidáris nemzetközi társadalma létrehozásának, mivel nem az államok együttélését, hanem azok együttmúködését kívánja biztosítani. (Schütze, 2012)

A fentebbiek alapján kijelenthető, hogy az Európai Unió továbbra is rendelkezik a nemzetközi szervezetekhez hasonlatos sajátosságokkal, amelyek alapján egy ilyen elméleti keret alkalmas a vizsgálatra. Elmondható, hogy Sinclair maga is olyan analógiát használ, amelyet az alkotmányjogi keretekből vesz át. Még ha el is fogadjuk azt, hogy az uniós jog nagyobb mértékú hasonlóságot mutat az alkotmányjoggal, mint a nemzetközi jog, arra juthatunk, hogy ez nem megkérdőjelezi, hanem inkább megerősíti egy, a Sinclair elméletéhez hasonlatos megközelítés alkalmazását. A továbbiakban az uniós hatáskörök kiterjesztését ezzel az előképpel kívánom vizsgálni.

Az Európai Unióról szóló Szerződés, [HL C 326., 2012. 10. 26., 13-390. o. (GA)]

A Bíróság C-26/62. sz. Van Gend en Loos kontra Administratie der Belastingen ügyben 1963. február 5-én hozott ítélete [ECLI:EU:C:1963:1];, a Bíróság (teljes ülés) 2/13. sz. az Európai Uniónak az emberi jogok és alapvető szabadságok védelméről szóló európai egyezményhez történő csatlakozása kapcsán 2014. december 18-án hozott vélemény [ECLI:EU:C:2014:2454] 157. és 158. pontja.

4 A Bíróság 1/91. sz. Megállapodás-tervezet az Európai Gazdasági Térség létrehozásáról egyrészről a Közösség, másrészről az Európai Szabadkereskedelmi Társulás tagjai között kapcsán 1991. december 14-én hozott véleménye [ECLI:EU:C:1991:490] 


\section{Az unió és a hatáskörök kérdése}

Alapvető, hogy az unió nem rendelkezik a jogalkotásra és a jogi aktusok elfogadására vonatkozó általános, minden területre kiterjedő hatáskörrel. Ez alapján az uniót több korlát is köti a hatáskörszerzésre vonatkozóan. (Blutman, 2014) Az Európai Unió működéséről szóló szerződés ${ }^{5}$ (a továbbiakban: EUMSZ) 5. cikkének (2) bekezdése szerint a „hatáskör-átruházás elvének megfelelően az Unió kizárólag a tagállamok által a Szerződésekben ráruházott hatáskörök határain belül jár el a Szerződésekben foglalt célkitűzések megvalósítása érdekében”. Ebből következően azok a hatáskörök, amelyeket a Szerződések nem ruháztak az Unióra, a tagállamoknál maradnak. Ennek érdekében a lisszaboni reform óta az EUMSZ 3-4. és 6. cikkei felsorolják a kizárólagos uniós hatásköröket, a megosztott hatásköröket és a támogató-összehangoló-kiegészítő hatásköröket. Az előbbieken túl további uniós jogi alapelveket listáz a szakirodalom, így a szubszidiaritást és az arányosságot, amelyek további gátként szolgálnak az unió számára. (Garben, 2011: 58-59) A gyakorlatból látható azonban, hogy ezek a szabályok nem tudtak véget vetni az úgynevezett hatáskör-kiterjesztés (competence creep) jelenségének. (Garben-Govaere, 2017:6-8)

A hatáskör-kiterjesztésre vonatkozóan a szakirodalom nem rendelkezik egy általánosan elfogadott definícióval. A szűk értelmezés alapján a kifejezés alatt csupán azt a jelenséget értjük, amikor az unió olyan területeken alkot jogot, amelyek esetén nincs kifejezett felhatalmazása, tehát nem rendelkezik hatáskörrel. (Kostantinides, 2009; Garben, 2017:2-4) Ez többnyire közvetett jogalkotás keretében következik be, amely mostanra az Európai Unió jogalkotásában jelentős problémává nőtte ki magát. A közvetett jogalkotás uniós jogi kontextusban azt jelenti, hogy az unió olyan területeken alkot jogot, amelyre alapvetően korlátozott mértékben vagy egyáltalán nem terjed ki a hatásköre. Ehhez gyakran az alapító szerződésekből eredő egyes funkcionális rendelkezéseket veszi igénybe. (Schütze, 2012:152-161; Garben, 2017:3) A két legjelentősebb eszköz a belső piaci jogalap (az EUMSZ 114. cikke), valamint a rugalmassági rendelkezés (az EUMSZ 352. cikke). Az előbbi teszi lehetővé azt, hogy a belső piac egysége érdekében a tagállamoknak kötelezettségükké váljék, hogy bizonyos kijelölt területeken harmonizálják jogrendszerüket. A második ezzel szemben egy sokkal általánosabb rendelkezés. Ez lehetővé teszi az unió számára, hogy ha a Szerződésekben meghatározott politikák keretében az unió fellépése szükséges ahhoz, hogy a Szerződésekben foglalt célkitűzések valamelyike megvalósuljon, de az ehhez szükséges hatáskör egyébként az unió számára nincs biztosítva, akkor meghozza az ehhez szükséges rendelkezéseket. Ebből következően a rendelkezés lehetővé teszi, hogy az EU olyan területeken is fellépjen, amelyeken egyébként nem rendelkezik kifejezett hatáskörrel, viszont bizonyos célok megvalósítása érdekében szükség lenne rá. Megjegyzendő, hogy a lisszaboni reformot követően a rugalmassági rendelkezés több korlátozást is kapott (a Tanács egyhangúsága és a tagállami parlamentek előzetes figyelmeztetése szükséges, valamint a kül- és biztonságpolitikával kapcsolatos célkitűzések ilyen módon történő megvalósítása kizárt), ugyanakkor továbbra is jelentős eszköz maradt az unió számára. (Garben, 2017:4)

Az Európai Unió Múködéséről szóló Szerződés, [HL C 326., 2012.10.26., 47-390. o. (GA)]

Európai Tükör 2020/1. 
A szúkebb fogalmi megközelítés azonban nem foglalja magában azokat a helyzeteket, amikor a Bíróság értelmezi az unió hatásköreit és ezzel újabb és újabb jellemzővel látja el az egyes hatásköröket, vagy amikor nemzetközi szerződések megkötésével kerül sor ilyen hatáskör-kiterjesztésre. (Ramalho, 2011:97; Davies, 2017) Mivel Sinclair elmélete rámutat arra, hogy a nemzetközi szervezet hatáskör-növekedése az egyszerú jogalkotásnál jóval sokrétűbb, logikus egy összetettebb hatáskörkiterjesztés-fogalmat alkalmazni. Ebből következően Garben (2017:3) meghatározását használom a továbbiakban, mivel az kellően sok eszközt és területet felölel ahhoz, hogy a hatáskör-kiterjesztésről átfogó képet lehessen alkotni. Eszerint a hatáskör-kiterjesztés hat formáját különböztethetjük meg: a közvetett jogalkotást, az esetjogon alapuló negatív integrációt, a nemzetközi szerződéseket, a gazdasági kormányzást, a soft law alkalmazását és a párhuzamos integrációt. A brit kilépés esetén az előbb felsoroltakból a szűkebb meghatározáson túl további két elemet tartok fontosnak alaposabban megvizsgálni, mivel azok a vizsgált kérdésben relevánsak lehetnek.

Először, a nemzetközi szerződések esetén két fő típus különíthető el a hatáskör-kiterjesztés esetén az eddig tapasztaltak alapján Ezek főként a közös kereskedelempolitikához kapcsolódnak. Az első esetben a kereskedelmi megállapodások bizonyos esetekben olyan területekre is hatással lehetnek, amelyek esetén egyébként a harmonizáció kizárt. (Garben, 2017:5-6) Ezt erősíti meg a Bíróság 2/15. sz. véleménye. ${ }^{6}$ Ez alapján a tagállamoknak a beruházásvédelem esetén oly módon kell gyakorolni hatásköreiket, hogy az nem fosztja meg az unió által tett kötelezettségvállalásokat hatékony érvényesülésüktől. A második esetben ezek az egyezmények a hatáskör-kiterjesztést úgy is megvalósíthatják, hogy a szabad mozgásból és a beruházásvédelemből fakadó kötelezettségek alapján korlátozzák a tagállami jogalkotásra vonatkozó hatásköröket. Mivel a tagállamok joga összhangban kell, hogy legyen a nemzetközi kötelezettségeikkel, így ez nagyban múlik azon is, hogy ki és hogyan értelmezi az ilyen megállapodásokban foglalt kötelezettségeket. (Garben, 2017:6) Megjegyzendő ugyanakkor, hogy a nemzetközi megállapodásokhoz kapcsolódóan csupán példákat sorol fel a szerző. A felsorolás így nem kimerítő jellegű, mivel azok kapcsolata az uniós hatáskörökkel állandó mozgásban van.

Másodszor, a gazdasági kormányzásra vonatkozó hatáskör-kiterjesztés jelensége is említést érdemel. Mivel ezek a kérdések a tagállami szuverenitást nagymértékben érintik, így a tagállamok óvakodnak attól, hogy ezen a téren további kompetenciákat engedjenek át az unió számára. Látható ugyanakkor, hogy a gazdasági válság kezelésekor az unió által foganatosított intézkedések több ilyen hatáskört is érintettek. Garben több példát hoz fel erre, ilyenek az Európai Szemeszter alapján adott országspecifikus ajánlások és az azok alapján megjelenő egyéb instrumentumok, amelyek kihatással vannak a tagállami autonómiára is. (Garben, 2017:7-8) Erre vonatkozóan megjegyzendőnek tartom, hogy ez a hatáskörkiterjesztés-típus valójában sokkal általánosabb okra vezethető vissza. Úgy vélem, hogy az unió hajlamos az egyes válsághelyzetekben ezzel az eszközzel élni. (Garben, 2017:8)

A Bíróság 2/15. sz. az Európai Unió és a Szingapúri Köztársaság közötti szabadkereskedelmi megállapodás kapcsán hozott vélemény [ECLI:EU:C:2017:376] 103. pontja. 
Jó példa erre a Pringle-ügy, ${ }^{7}$ amelyet azonban a szerző a párhuzamos integráció egy példájaként nevez meg, vagyis amikor a tagállamok az unió keretén kívül működnek együtt, ugyanakkor az uniónak valamely okból mégis ráhatása van az adott hatásköri kérdéskörre. Az ügy fő kérdése az volt, hogy mennyiben volt az uniós tagállamoknak joga arra, hogy az Európai Stabilitási Mechanizmus elfogadására vonatkozó nemzetközi egyezményt az uniós jog alapján megkössék. Ezen ügy esetén több kérdés is felvetődött a hatáskörök kérdésére vonatkozóan. Először is, a krízis kezelése kapcsán felmerült, hogy egy ilyen nemzetközi egyezmény megkötése mennyiben egyeztethető össze az EUMSZ 3. cikk (1) bekezdésének c) pontjával, amely szerint a gazdasági és monetáris unió kérdései az unió kizárólagos hatáskörébe tartoznak, és ez meggátolná azt, hogy a tagállamok ilyen megállapodást kössenek az EUMSZ 3. cikk (2) bekezdése szerint. A Bíróság azonban úgy találta, hogy egy ilyen megállapodás megkötése nem ellentétes az unió hatásköri elosztásával, mivel az ESM tevékenységei nem tartoznak a monetáris politika hatálya alá, minthogy a mechanizmus célja nem az árstabilitás fenntartása (95-107. pontok). Másodszor, az is kérdés volt, hogy mennyiben tekinthető az uniós joggal összeegyeztethetőnek az, hogy a nemzetközi szerződés újabb feladatokat ró az uniós intézményekre, így a Bizottságra, az Európai Központi Bankra és a Bíróságra. Erre vonatkozóan a Bíróság végül megállapította, hogy mivel ezek a feladatok az uniós jogban megállapított intézményi kötelezettségekkel összeegyeztethetőek, azokat alapjaiban nem változtatja meg, így nem merül fel jogi probléma (153-182. pontok). Jól látható ugyanakkor, hogy ez az unió mozgásterének bővítéséül szolgál a válság megfelelő kezelése érdekében. (Garben, 2017:8) Látható, hogy a példa Garbennél elkülönül, ugyanakkor mégis egy válságra való reakcióként értelmezhető mindkettő.

Ezek alapján az uniónak számos lehetősége van arra, hogy módosítsa érdemben az unió és a tagállamok közötti hatásköri status quót. Erre vannak egészen jól látható és egyértelmű eszközök, mint amilyen a közvetett jogalkotás, vagy elsőre éppen kevésbé látványosak, ahogy azt a nemzetközi szerződések helyzete is mutatja. Álláspontom szerint ezek némiképpen az unió nemzetközi társadalmának erôsítésére, az arra vonatkozó kihívások kezelésére is irányulhatnak, mint ahogy arra Sinclair elmélete is rámutat más nemzetközi szervezeteknél.

Érdemes a fentebbiekből következően megvizsgálni, hogy egy olyan esetben, mint például az Egyesült Királyság kilépése, ez a jelenség milyen módon jelenhet meg, és melyek azok a helyzetek, amelyek során a folyamat ellentmondásos természete megjelenik a hatáskörök esetén.

\section{Az Egyesült Királyság kilépése és a fóbb uniós jogi problémakörök}

Az Egyesült Királyság tagsága alatt egy sajátos különutas politikát folytatott, és a brit belpolitikán belül szinte végig jelen voltak az euroszkeptikus hangok is. (Budai, 2019:35)

A Bíróság (teljes ülés) C-370/12. sz. Thomas Pringle kontra Government of Ireland és társai ügyben 2012. november 27-én hozott ítélete [ECLI:EU:C:2012:756]

Európai Tükör 2020/1. 
Ezt a 2008-as gazdasági válság még inkább tetézte. Az akkori brit miniszterelnök, David Cameron legfőbb céljának tekintette, hogy az Egyesült Királyság és az EU közötti viszonyt újratárgyalja. Az EU azonban hiába tett engedményeket, 2016. június 23-án megtartották az Egyesült Királyság uniós tagságáról szóló népszavazást, amely során a szavazók 52\%-a döntött az európai integrációból való kilépés mellett. (Sampson, 2017) Az Egyesült Királyság ezt követően 2017. március 29. napján jelentette be kilépési szándékát. (Dammann, 2017:267)

\section{A kilépés uniós jogi háttere}

Elmondható, hogy a kilépés kérdéskörének szabályozása viszonylag újszerű az uniós jogban, ugyanakkor maga a probléma nem újkeletű. A Római Szerződés idejében a Német Szövetségi Köztársaság (NSZK) fenntartotta magának azt a jogot, hogy a Német Demokratikus Köztársasággal (NDK) való esetleges újraegyesülése esetén felülvizsgálja uniós tagságát. (Blanke-Mangiameli eds., 2013:1386) Emellett az Alkotmányszerződés tárgyalásai során már a cikk több tervezete is létezett. Ezek már többek között rögzítették azt, hogy a kilépésre vonatkozó döntés a kilépő állam alkotmányos szabályainak megfelelően kell, hogy történjen. Ezen túl a kilépés eljárására vonatkozóan arról is rendelkezett, hogy a Tanácsnak szerződést kell kötnie az adott tagállammal, amelyet a többi tagállamnak el kell fogadnia az Európai Parlament beleegyezésével, és ennek megkötésére egy kétéves időszak áll rendelkezésre. Végül a rendelkezés az Alkotmányszerződés szövegébe is belekerült. (Budai, 2017:36) A rendelkezés jelenlegi formája a Lisszaboni Szerződés módosításával vált részévé az EUSZ szövegének. Ennek célja az volt, hogy a kilépésre vonatkozó kérdéskört ne a nemzetközi jog, hanem elsődlegesen az uniós jog szabályozza. (Blanke-Mangiameli eds., 2013:1396) A másodlagos célt maga a szöveg készítője és korábbi brit diplomata, John Kerr nevezte meg, miszerint ha egy tagállam diktatórikus rendszert vezetne be, akkor azon államnak biztosítani kell a kilépés lehetőségét tagságának felfüggesztése esetében. (Gray, 2019)

Az EUSZ 50. cikk (1) bekezdése alapján a tagállam a saját alkotmányos követelményeivel összhangban határozhat úgy, hogy kilép az Európai Unióból, vagyis az nem egy tagállami kormány döntése, hanem alkotmányosan feljogosított intézményeknek az alkotmányjogi kereteknek megfelelően lefolytatott eljárása alapján meghozott döntés. (Blanke-Mangiameli eds., 2013:1406) Az 50. cikk (2) bekezdése alapján a tagállam az Európai Tanácsnak bejelenti az erre irányuló (tehát kifejezett és célzatos) szándékát, amely a britek esetén 2017. március 29-én történt meg. Nem szükséges hozzá, hogy az unió vagy a többi tagállam a beleegyezését adja. Korábban a szakirodalom nem volt egységes állásponton arra vonatkozóan, hogy lehetséges-e a szándéknyilatkozat viszszavonása. (Louis, 2006:293-294; Weatherhill, 2018) A Bíróság a kérdésre a Wightmanügy ${ }^{8}$ során adott választ. A szóban forgó esetben a Bizottság és a Tanács úgy érvelt, hogy abban az esetben, ha a szándéknyilatkozat visszavonható lenne, akkor bármikor megkerülhetné az EUSZ 50. cikkében foglalt szabályokat (főleg a határidők esetén), amely

Az EUB (teljes ülés) C-621/18. sz. Wightman és társai ügyben 2018. december 10-én hozott ítélete [ECLI:EU:C:2018:999] 
lehetővé tenné a visszaéléseket az EU kárára (38-42. bekezdések). A Bíróság ezzel szemben hangsúlyozta, hogy mivel a szöveg a szándék kifejezést használja, így az „jellegénél fogva nem végleges és nem is visszavonhatatlan”. Emellett a saját alkotmányos követelményeivel összhangban nyilvánítja ki ezt a szándékot, ebből következően nem kell azt a többi tagállammal vagy akár az uniós intézményekkel egyeztetnie (47. bekezdés).

Elmondható, hogy uniós jogi szempontból az EUSZ 50. cikke az, amely rendelkezés gyakorlatilag alapjául szolgál(t) a Brexit folyamatának, és jelenleg a legfontosabb sarokköveit képező kilépési megállapodásnak, a Bizottság megállapodás nélküli kilépési szabálycsomagjának, valamint a jövőbeli kapcsolatrendszerre vonatkozó politikai nyilatkozatnak. A következőkben ezeket vizsgálom.

\section{A kilépési megállapodás}

Az EUSZ 50. cikk (2) bekezdése a kilépési eljárásra vonatkozóan rendelkezik arról, hogy az EU az Európai Tanács iránymutatásaival összhangban tárgyalásokat folytat és megállapodást köt a kilépő tagállammal, amely megállapodásban az érintett államnak az unióval való jövőbeli kapcsolataira tekintettel határozzák meg a kilépés szabályait. A brit esetben az iránymutatások rögzítették többek között ennek megfelelően az alapelveket, a tárgyalásokra vonatkozó szakaszos megközelítést, az előkészítő megbeszélések részletes kereteit, a lojális együttmüködés elvét, valamint az 50. cikk szerinti tárgyalások eljárási szabályait. (Prieger-Klemm, 2019:15) Az uniós jog a megállapodás megtárgyalására vonatkozóan az EUMSZ 218. cikket rendeli alkalmazni, mivel itt már valójában egy nemzetközi szerződés megkötéséről van szó. Ez azt is jelenti, hogy a folyamatra nem csupán egy kormányközi megállapodásként tekinthetünk, vagyis nem csupán a Tanács jut jelentős szerephez az eljárás során, hanem az unió azon intézménye is, amely az EUSZ 17. cikke alapján előmozdítja az unió általános érdekeit, vagyis maga a Bizottság. (Gatti, 2017:170)

Az EUMSZ 218. cikke alapján a Bizottság ajánlásokat nyújt be a Tanácsnak, amely a tárgyalások megkezdéséről határozatot fogad el. Ebben a Tanács kijelöli az unió főtárgyalóját vagy a tárgyaló küldöttségének vezetőjét. A kilépési megállapodás kitárgyalásakor a Bizottság látta el ezt a feladatot. Megjegyzendő, hogy az EUMSZ 207. cikk (3) bekezdése alapján a közös kereskedelempolitikához tartozó nemzetközi megállapodásokat a Bizottság tárgyalja. Emellett az EUSZ 17. cikkéből következően is a kizárólagos és a megosztott hatáskörök érintettsége esetén (a közös kül- és biztonságpolitikához tartozó kérdésköröket leszámítva) a megállapodást fő szabály szerint a Bizottság tárgyalja. (Gatti, 2017:170; Európai Bizottság, 2011:33-34) Abban az esetben, ha a tárgyalások kizárólagos tagállami hatáskörökhöz kapcsolódnak, a lehetőség szintén megvan arra, hogy a Bizottság legyen a tárgyaló. Különösen kétoldalú tárgyalások esetén ez maradt a hagyományos megközelítés. (Hoffmeister, 2015:140-141)

Az EUSZ 50. cikk (2) bekezdése szerint magát a megállapodást az unió nevében az Európai Unió Tanácsa (a továbbiakban: a Tanács) köti meg minősített többséggel, amelyhez szükséges az Európai Parlament egyetértése is. Ezeknek a döntéseknek a meghozatalában a kilépő tagállam nem vesz részt. 
Elmondható azonban, hogy az uniós jognak a kilépési megállapodás megkötésére vonatkozó szabályait az EUSZ 50. cikke nem tartalmazza, azt sokkal inkább a gyakorlat formálta ki. Talán az egyik legfontosabb, hogy habár az 50. cikk (2) bekezdése arra utal, hogy egyetlen ilyen megállapodásról van szó, amely meghatározza a kilépő tagállam és az unió jövőbeli kapcsolatait, valójában a kilépési megállapodás nem rendezi ezeket a kapcsolatokat teljes egészében. Erre vonatkozóan a megállapodás 126. cikke egy átmeneti időszakot, vagyis egy olyan időintervallumot jelölt ki, amely esetén a kilépési megállapodás hatályosulásától egészen 2020 végéig az uniós acquis túlnyomó része továbbra is alkalmazandó az Egyesült Királyságra. Ez alól kevés szabály - így az Egyesült Királyságnak az uniós döntéshozatalban való részvételére vonatkozó uniós szabályok - a kivétel.

Maga a megállapodás ${ }^{9}$ rámutat arra, hogy az uniós jog milyen sokrétúen szabályozza a tagállamok és azok állampolgárainak viszonyait. A megállapodás kiemelten foglalkozik a polgárok jogaival, amely magában foglalja a szabad mozgásra, tartózkodásra, de még a társadalombiztosításra vonatkozó rendelkezéseket is (II. rész), valamint a pénzügyi rendelkezésekkel (V. rész). Elkülönülten kezeli ugyanakkor az egyes szakpolitikákra vonatkozó szabályozásokat, úgymint a büntetőjogi együttmúködés, a szerzői és iparjogvédelmi kérdések, a közbeszerzés, az adatvédelem és a Bíróság függőben lévő ügyeinek rendezése (III. rész). A megállapodás ezen túl az intézményi rendelkezésekkel (VI. rész) zárul, amely rendelkezik a vitarendezési kérdésekről és a döntéshozó mechanizmusokról. Megjegyzendő, hogy a kilépési megállapodáshoz három jegyzőkönyv is kapcsolódik: az első az ír határkérdéssel, a második az Egyesült Királyságnak Ciprus területén levő bázisaival, míg a harmadik Gibraltár helyzetével foglalkozik.

\section{A megállapodás nélküli kilépés esetére alkotott szabálycsomag}

Mivel az EUSZ 50. cikke kétéves tárgyalási folyamatot ír elő, így a kilépésnek fô szabály szerint a bejelentéstől számított két év elteltével, 2019. március 29. napjának végével kellett volna bekövetkeznie. Megjegyzendő, hogy az uniós jog lehetőséget ad az ettől való eltérésre a cikk (3) bekezdése szerint, ha „az Európai Tanács az érintett tagállammal egyetértésben ennek a határidőnek a meghosszabbításáról egyhangúlag határoz". Egyes vélemények már a Brexit előtt kevesellték a kétéves időszak hosszúságára vonatkozó időszakot, amely aggályt a gyakorlat később igazolta is. (Blanke-Mangiameli eds., 2013:1407) Az Egyesült Királyság kilépési folyamata végül három alkalommal került meghosszabbításra, amelynek következtében mind a közbeszédben, mind a magas politikai szinten megjelent a megállapodás nélküli kilépés bekövetkezésének veszélye, vagyis az, hogy a britek mintegy kizuhannak az EU-ból, még mielőtt megfelelő szabályozás kerülne elfogadásra az esetre. Az úgynevezett no-deal uniós oldalról főleg az Egyesült Királyság területén levő uniós polgárok helyzetét tette volna bizonytalanná, de Észak-Írország esete is komoly kihívást jelentett volna, főleg a nagypénteki egyezmény által létrejött politikai kiegyezés és az ahhoz kapcsolódó részletkérdések, mint például a határellenőrzés és a kapcsolódó vámszabályozási kérdések miatt. (Wolff, 2019; Egedy, 2018)

A Nagy-Britannia és Észak-Írország Egyesült Királyságának az Európai Unióból és az Európai Atomenergia-közösségből történő kilépéséről szóló megállapodása, [HL L 29., 2020.1.31., 7-187. o.] 
Ennek orvoslására az Európai Bizottság több jogalkotási javaslattal állt elő, amely a megállapodás nélküli kilépés esetére dolgozott ki jogszabályokat egyes szakpolitikai területeken, amelyek főként rendeleti formában kerültek elfogadásra. Ezek főként a vámok, az energiapolitika, a pénzügyi szolgáltatások, de a légi közlekedés és a társadalombiztosítás területeire is írtak volna elő a megállapodás nélküli kilépés esetén alkalmazandó szabályokat. (Európai Bizottság, 2018) A szabályozást végül - mivel a kilépési megállapodás hatályba lépett - nem alkalmazták.

\section{A politikai nyilatkozat és a tárgyalási mandátum}

Mintegy harmadik fő kérdéskörként megjegyzendő, hogy a kilépési megállapodás mellett elfogadásra került egy úgynevezett politikai nyilatkozat ${ }^{10}$ is, amelyet magához a megállapodáshoz csatoltak. Amíg a kilépési megállapodás arra irányult, hogy a kilépéssel kapcsolatos és az átmeneti időszakra vonatkozó uniós jogi kérdéseket rendezze, addig a politikai nyilatkozat a jövőbeli kapcsolatok kereteit kívánta meghatározni. Ennek kitárgyalására a dokumentum 2020 végét jelöli meg, ugyanakkor jelenleg ez az időpont nem tekinthető reálisnak, ha egy teljes körű megállapodás alapos kitárgyalásáról van szó. (Peers, 2019) A nyilatkozat nem tartalmaz a tárgyalások menetéről rendelkezéseket, ugyanakkor nem is ez a célja. Számos szakpolitikát, így az adatvédelmet, a vámügyeket, a szolgáltatásokat, a befektetéseket, a közlekedést, a büntetőügyekben folytatott együttmúködést és a biztonsági és védelmi kérdéseket érintő fő kívánalmakat fogalmaz meg a jövőbeli együttműködésre vonatkozóan.

Kiegészítendő, hogy a cikk megírásakor már mind a brit, mind az uniós fél nyilvánosságra hozta a saját mandátumát a jövőbeli kapcsolatok megtárgyalására. (Peers, 2020) Az unió részéről az erre vonatkozó dokumentumot ${ }^{11}$ az EUMSZ 218. cikk (3) bekezdése fogadja el a Tanács minősített többséggel, csakúgy, mint a kilépési megállapodás esetén. Itt ugyanakkor nyilvánvalóbb ezen szabály alkalmazása, mivel az Egyesült Királyság itt már mint harmadik állam van jelen. A dokumentum 169-172. bekezdései alapján a Tanács a Bizottságot jelölte ki arra, hogy lefolytassa a tárgyalásokat. A dokumentum hasonló tárgyköröket tartalmaz, mint a politikai nyilatkozat: kitér az adatvédelem, az áruk és szolgáltatások, a szellemi tulajdon, a közbeszerzés, a közlekedés, a halászat kérdéseire, az Egyesült Királyságnak az uniós programokban való részvételére, ugyanakkor részét képezik a biztonsági együttműködésre és a külpolitikára vonatkozó iránymutatások is.

Political Declaration Setting Out the Framework for the Future Relationship between the European Union and the United Kingdom, [2020/C 34/01]

11 Directives for the negotiation of a new partnership with the United Kingdom of Great Britain and Northern Ireland, [5870/20 ADD 1 REV 3] 


\section{Lehetséges hatásköri kérdések}

\section{A kilépési megállapodás kérdése}

Elmondható, hogy mivel a kilépési megállapodás szövegét kitárgyalták, és annak szövegében részletesen lehatárolták az egyes szakpolitikai kérdéseket és tárgyköröket, nem merül fel hatásköri probléma. Habár az EUSZ szövegéhez képest némi eltérés van abban, hogy pontosan hány megállapodást is kötnek a felek, annak szövege, valamint az ahhoz kapcsolódó esetleges dokumentumok nem utalnak arra, hogy az unió és a tagállamai között hatásköri probléma merülne fel.

\section{A no-deal csomag kérdése}

Noha a csomag nem lépett hatályba, bizonyos tekintetben kapcsolódik a hatásköri kérdésekhez. Erre vonatkozóan két megjegyzést érdemes tenni.

Először, a no-deal során alkotott szabálycsomag esetén egy esetben merül fel kifejezetten hatásköri kérdés. A Nagy-Britannia és Észak-Írország Egyesült Királyságának az unióból történő kilépésével összefüggésben az alapszintû légi összeköttetést biztosító közös szabályokról szóló 2019. március 25-i (EU) 2019/502 rendelete ${ }^{12}$ rendelkezik bizonyos, a tagállamok hatáskörébe tartozó rendelkezésekről kifejezetten. A rendelet azt a helyzetet kívánta megelőzni, hogy egy rendezetlen kilépés esetén nem lenne tovább alkalmazandó a légi járatok működtetésére vonatkozó közös szabályokról szóló 2008. szeptember 24-i 1008/2008/EK rendelet az Egyesült Királyság és a többi uniós tagállam tekintetében, amely így minden uniós jogot és kötelezettséget megszüntetett volna a területre vonatkozóan. Ennek érdekében kellett olyan ideiglenes intézkedéseket hozni, amely a no-deal esetén lehetővé tette volna az Egyesült Királyságban engedélyezett légi fuvarozók számára, hogy légi járatot üzemeltessenek az Egyesült Királyság és a fennmaradó 27 tagállam között.

A rendelet 4. cikke ugyanis forgalmi jogokat biztosított volna megállapodás nélküli kilépés esetén, mint amilyen az unió területe felett való átrepülés leszállás nélkül vagy éppen menetrend szerinti légi járatok üzemeltetése. Ezt a kérdést ugyanakkor a rendelet megfelelően rendezi annak 2. cikkében. Annak (1) bekezdése szerint egy esetleges no-deal időszak végét követően „az Unió haladéktalanul megszünteti az említett hatáskör gyakorlását, és a tagállamok az [EUMSZ] 2. cikkének (2) bekezdésével összhangban újból gyakorolják hatáskörüket". Emellett kimondja, hogy a hatáskörnek a rendelet alapján történő gyakorlása nem érinti a tagállamok forgalmi jogokra vonatkozó hatáskörét. Megjegyzendő, hogy a rendelet szövege meglehetősen körülhatárolt, és valóban ideiglenes jelleggel „vesz át” egy kizárólagos tagállami hatáskört. Ez a szabályozás jól láthatóan egy meglehetősen szokatlan megközelítés és kezelése egy nehéz helyzetnek.

Másodszor, némi párhuzam fedezhető fel a gazdasági válság során tett intézkedéscsomaggal. Abban az esetben az indokolás az volt, hogy az EU könnyebben tudja az adott problémákat megfelelően kezelni a saját szintjén. Elmondható, hogy azon

[HL L 85I., 2019.3.27., 49-59. o.] 
a területen levő hatáskörmódosulásnál is hasonló az indokolás összességében. (Garben, 2017:7) Megjegyzendő, hogy a 2019/502 rendelet (12) preambulumbekezdése is hasonlóan érvel, amely szerint a rendelet célját „a tagállamok nem tudják kielégítően megvalósítani”, éppen azért az EUSZ 5. cikkében foglalt szubszidiaritás elvére hivatkozva ideiglenesen vonja el a hatáskört. Gyakorlatilag mindkét esetben egy speciális helyzet miatt a tagállamok bizonyos szintig lemondtak hatáskörükről annak érdekében, hogy az unió egy komoly veszélyhelyzetet megfelelően kezelhessen. Az indokolás meglehetősen ellentmondásos annak fényében, hogy az 1008/EK rendelet valójában egyes jogosítványokat azért hagy a tagállamoknál, mert az nem tartozik uniós hatáskörbe, nem indokolja semmi, hogy azokat kielégítően csak uniós szinten lehet megvalósítani. Egy esetleges, az uniót érintő válság léte nem kerül jelen esetben jogi nyelven megfelelően dekódolásra, valójában nem egyértelmű az uniós jog logikájából, miért kellene ideiglenesen egy egyébként tagállami hatáskört uniós szinten szabályozni.

Harmadszor, az előzőből következően egy további észrevétel tehető mintegy általános jelleggel a no-deal csomag esetén. Az mindenképpen elfogadható, hogy az egyes válságok esetén az uniónak szerepet kell vállalnia abban, hogy a válságot megfelelően kezelje, mivel lényeges számára annak fenntartása az angol iskola szerint. (AhrensDiez, 2015) Elmondható, hogy mind a 2008-as gazdasági válságra adott válaszok, mind a no-deal csomag esetén válaszként reagál az unió a kihívásokra, erre mintegy eszköz az uniós jog (ahogy az következik is a tanulmánynak A két komponens összefüggései című alfejezetéből). Megállapítható ugyanakkor, hogy az uniós jogon belül nincs rögzítve egy kellően szilárd szabályrendszer arra vonatkozóan, hogy az uniónak mely tárgykörök esetén és milyen mértékű lehet ez a szerepvállalása. A fentebbi példából látható, hogy a szubszidiaritás elve nem bizonyul elegendő korlátnak arra, hogy az unió ideiglenesen ne tagállami hatáskörben alkosson jogot még akár ideiglenes jelleggel is. Garben és Goavere azon állítása, hogy a szubszidiaritás elve (de akár a hatáskörök taxatív felsorolása is) nem elégséges korlát, ebből következően igazolható. (Garben-Govaere, 2017:6-8) Fennáll a lehetősége annak is, hogy a hatáskörök tartalma elmosódik, bizonytalanná válik. Ez pedig igazolja a Sinclair által felvázolt alkotmányos növekedés jelenségét is. (Sinclair, 2017)

\section{A jövöbeli kapcsolatrendszerre vonatkozó dokumentumok helyzete}

Az egyértelmű, hogy az Egyesült Királyság kilépésével számos olyan, a jövőbeli kapcsolatrendszerre vonatkozó kérdés felmerülhet, amelyet az uniós jog nem szabályoz. A politikai nyilatkozatban és a tárgyalási mandátumban szereplő kérdéskörök ugyanakkor sokkal általánosabb jellegúek, mindössze iránymutatásokat tartalmaznak a jövőbeli kapcsolatok kereteire vonatkozóan, ebből következően érinthetnek akár megosztott (például halászat, légi közlekedés, bel- és igazságügyi együttmüködés), akár kizárólagos tagállami hatáskörbe tartozó kérdéseket (egyes külpolitikai kérdések, egészségügy) is. Elmondható, hogy a tárgyalási mandátumnak a Bizottság által javasolt verziója a jövőbeli partnerség tekintetében egy egységes csomagot irányoz elő, amely magában foglalná az általános rendelkezéseket és a gazdasági, valamint a biztonsági kérdéskörre vonatkozó jövőbeli kapcsolatrendszert érintő szabályokat egyaránt. (Európai Bizottság, 
2020:3) Az erre való utalás azonban már nem szerepel explicite a dokumentum tanácsi verziójában. (Peers, 2020) Elmondható ugyanakkor, hogy mindkét verzió hivatkozik jogalapként mind az EUMSZ 218. cikk (3) és (4) bekezdésére, mind a 217. cikkre mint a társulási megállapodásra vonatkozó jogalapra. Megjegyzendő, hogy a megkötendő megállapodás tárgyi hatálya a jövőben növekedhet vagy szűkülhet. Jelenlegi formájában azonban nagy valószínűséggel egy vegyes megállapodás megkötéséről beszélhetünk. (Budai, 2019)

Vegyes megállapodásnak az olyan nemzetközi szerződéseket nevezzük, amelyek szerződő felei az unió és annak (bizonyos) tagállamai a szerződés „egyik oldalán” és a nemzetközi jog egy alanya (állam vagy nemzetközi szervezet) annak „másik oldalán”. Ebből következően a megállapodást nemcsak az uniónak kell elfogadnia az uniós szabályoknak megfelelően, de a tagállamoknak is azok saját alkotmányos követelményei alapján. (Chamon, 2019) Ennek előnye, hogy a tagországok az uniót közvetlen ellenőrzésük alatt tarthatják, valamint összekapcsolják egymással az uniót és a tagállamokat, ezáltal komplex tartalmú megállapodások megkötésére és végrehajtására nyílik lehetőség. (Kengyel, 2010:note 6) Ennek megfelelően a Bíróság joggyakorlata ${ }^{13}$ alapján a tagállamoknak és az uniónak szorosan együtt kell múködnie a megállapodás kitárgyalása, megkötése és teljesítése során egyaránt.

Ezen megállapodásoknak jellemzően két fajtáját különböztetjük meg: a kötelező és a fakultatív vegyes megállapodásokat. Az előbbi esetében vannak olyan rendelkezései a nemzetközi egyezménynek, amelyek kizárólagos uniós hatáskörbe, és vannak olyanok, amelyek kizárólagos tagállami hatáskörbe tartoznak. Fakultatív vegyes megállapodásokról akkor beszélhetünk, amikor a rendelkezések kizárólagos uniós hatáskörhöz és megosztott hatáskörhöz tartoznak. Ilyen esetben az unió megköthetné a megállapodást önállóan is, mégis részt vesznek a tagállamok a folyamatban. (Chamon, 2019) A gyakorlat azt mutatja, hogy számaiban sokkal gyakoribbak a vegyes megállapodások a nem vegyesekhez képest. A tagállamok mintegy ragaszkodnak ahhoz, hogy továbbra is részesei legyenek a nemzetközi megállapodásoknak. (Kuijper et al., 2016:101) Ez mind a két típusú vegyes megállapodásnál így van, valamint akár a társulási megállapodások esetén is. (Chamon, 2019)

Megjegyzendő ugyanakkor, hogy mindezek ellenére komoly kérdések merülnek fel az elfogadással kapcsolatban. Az már világos, hogy a brit fél több ízben is határozottan állást foglalt abban, hogy nem kívánja meghosszabbítani az átmeneti időszakot, vagyis 2020. év végéig kell mindkét fél részéről egy (vélhetően?) nagyrészt teljes átfogó megállapodást elfogadni. (Peers, 2020) Ez alatt az idő alatt nemcsak a megállapodás szövegét kellene véglegesíteni, de azt mind az uniónak, mind az Egyesült Királyságnak, mind a tagállamok parlamentjeinek el kellene fogadni, ennek időbeli realitása kétséges. Ez a probléma nem újkeletű, az EU és Kanada között létrejött átfogó gazdasági és kereskedelmi megállapodás (CETA) esetében is megjelent, mivel annak elfogadása a Vallon Régió parlamentje miatt csúszott. Ezzel összefüggésben felvethető, hogy a nemzetközi

A Bíróság 1/94. sz. a Közösség hatásköre a szolgáltatásokról és a szellemi tulajdon oltalmáról szóló nemzetközi szerződések megkötése kapcsán hozott vélemény [ECLI:EU:C:1994:384] 108. pontja; A Bíróság 2/91. sz. a Nemzetközi Munkaügyi Szervezet 170. sz. egyezménye kapcsán hozott vélemény [ECLI:EU:C:1993:106] 36. pontja 
megállapodás ilyen esetekben ideiglenesen alkalmazható. ${ }^{14}$ Megjegyzendő ugyanakkor, hogy még egy ilyen forgatókönyv megvalósulása esetén sem lennének alkalmazhatóak a tagállamok kizárólagos hatáskörébe tartozó szabályok. Ez a probléma természetesen a tagállamok által már korábban tanúsított közös fellépéssel kiküszöbölhető.

Kérdés természetesen, hogy idő hiányában elfogadható-e a tagállamok nélkül egy ilyen megállapodás. Álláspontom szerint szinte biztosra vehető, hogy a kérdésre nem a válasz, a nemzetközi megállapodásokkal kapcsolatos hatáskörök helyzete esetében egy ilyen lépés precedensértékű lehet és a hatáskör-kiterjesztés veszélyét hordozza magában, amely a későbbiekben is hivatkozható lehet. Másrészről ez ugyanazt a problémát hívja életre, amelyet már A no-deal csomag kérdése címú alfejezetben említettem. Nem látható, hogy az uniónak a válságra adott válasza az uniós jog területén milyen határok között is mozog. A fentebbiek alapján egyértelmű, hogy az uniós alapító szerződésekben a hatáskörök rögzítése, valamint a szubszidiaritás elve nem szab megfelelő határokat ennek a problémának a kezelésére. Még ha meg is történik, hogy a tagállamok elfogadják, hogy az unió maga kösse meg a megállapodást, az idő hiánya valójában egy kényszerhelyzet, amely alapján így megkérdőjelezhető, hogy a tagállamok saját akaratukból engedik-e ezt meg.

\section{Záró gondolatok}

A Brexit folyamata jól mutatja, hogy az unió egyes kihívásai milyen ellentmondásokat képesek generálni az uniós jog számára. Mivel az ilyen kihívások sokszor „jobb híján” megoldásokat alkalmaznak, a mélyre nézve gyakran lehet találkozni diszkrepanciákkal. Megjegyzendő ugyanakkor, hogy az uniós jog területén sokszor ezek azok, amelyek táptalajul szolgálnak az unió hatáskör-kiterjesztésének Garben elmélete szerint. Ez akár olyan kényes esetekben, mint a hatáskörök kérdése is megjelenik, elegendő, ha a no-deal csomagot és a jövőbeli kapcsolatrendszer kérdéskörét vizsgáljuk. Látható, hogy a kilépési megállapodás esetén ez a probléma fel sem merül, mivel egy alaposan vizsgált és kitárgyalt dokumentumról van szó. A másik két fő csoport ezzel szemben kevesebb figyelmet kapott eddig, vagy nem került alkalmazásra.

Látható ugyanakkor, hogy a bemutatott elméleti háttér, vagyis az angol iskolának a Guy Fiti Sinclair által kidolgozott részekből álló keretrendszere ezt valamelyest kontextusba helyezi. A fentebb bemutatott diszkrepanciák mögött lényegében az a cél húzódik meg, hogy az unió a már létező nemzetközi társadalmát bizonyos módon megvédje, megőrizze. Ez azonban sokszor ellentmondásokkal teli, és egymással nehezen összeegyeztethető elemekből tevődik össze. Egyértelmű, hogy a Brexit folyamata még nem záródott le, mivel a jövőbeli kapcsolatrendszer és az annak alapjául szolgáló nemzetközi egyezmények kitárgyalása még várat magára. Erősen kétséges azonban, hogy a folyamat végére feloldódik-e valamelyest az ellentmondás.

14 Értesítés az egyrészről Kanada, másrészről az Európai Unió és tagállamai közötti átfogó gazdasági és kereskedelmi megállapodás (CETA) ideiglenes alkalmazásáról (2017). OJ L 238, 16.9.2017. 9-9. 


\section{Felhasznált irodalom}

Ahrens, Bettina (2019): The European Union Between Solidarist Change and Pluralist Re-Enactment. In Knudsen, Tony B. - NAVARI, Cornelia eds.: International Organization in the Anarchical Society. New York, Palgrave Macmillan. 265-292. DOI: https://doi.org/10.1007/978-3-319-71622-0_11

Ahrens, Bettina - Diez, Thomas (2015): Solidarisation and Its Limits: The EU and the Transformation of International Society. Global Discourse, Vol. 5, No. 3. 341-355. DOI: https://doi.org/10.1080/23269995.2015.1053189

BARKIn, Samuel J. (2003): Realist Constructivism. International Studies Review, Vol. 5, No. 2. 325-342. DOI: https://doi.org/10.1046/j.1079-1760.2003.00503002.x

Blanke, Hermann-Josef - MANgiAmeli, Stelio eds. (2013): The Treaty on European Union (TEU) - A Commentary. Berlin, Springer-Verlag. DOI: https://doi.org/10.1007/9783-642-31706-4

BLUtman László (2014): Az Európai Unió joga a gyakorlatban. Budapest, HVG-ORAC Lapés Könyvkiadó Kft.

BudAI, Péter (2019): „Not so splendid isolation” - Az Egyesült Királyság kilépésének főbb uniós jogi aspektusai. Fontes Iuris, 5. évf. 2. sz. 35-41.

Bull, Hedley (2012): The Anarchical Society: A Study of Order in World Politics. New York, Palgrave Macmillan. DOI: https://doi.org/10.1007/978-1-349-24028-9

Bull, Hedley - Watson, Adam (1984): Conclusion. In Bull, Hedley - Watson, Adam eds.: The Expansion of International Society. Oxford, Oxford University Press. $425-435$.

Buranelli, Filippo Costa (2019): Global International Society, Regional International Societies and Regional Organizations: A Dataset of Primary Institutions. In Knudsen, Tony B. - NAVARI, Cornelia eds.: International Organization in the Anarchical Society. New York, Palgrave Macmillan. 233-263. DOI: https://doi. org/10.1007/978-3-319-71622-0_10

BuzAN, Barry (1993): From International Society to International System: Structural Realism and Regime Theory Meet the English School. International Organization, Vol. 47, No. 3. 327-352. DOI: https://doi.org/10.1017/S0020818300027983

BuzAn, Barry (2004): From International to World Society? - English School Theory and the Social Structure of Globalisation. Cambridge, Cambridge University Press. DOI: https://doi.org/10.1017/CBO9780511616617

ChAmon, Merijn (2019): The Law and Practice of Mixed Agreements. Lecture at the 5th CLEER Summer School on EU External Relations Law.

DAmmanN, Jens (2017): Revoking Brexit: Can Member States Rescind their Declaration of Withdrawal from the European Union. Columbia Journal of European Law, Vol. 23, No. 2. 265-287.

Davies, Gareth T. (2017): The Competence to Create an Internal Market: Conceptual Poverty and Unbalanced Interests. In GARBEn, Sacha - GovaEre, Inge eds.: The Division of Competences between the EU and the Member States - Reflections on the Past, the Present and the Future. Oregon, Hart Publishing. 74-89. DOI: https://doi. org/10.2139/ssrn.2971940 
Diez, Thomas - Manners, Ian - Whitman, Richard G. (2011): The Changing Nature of International Institutions in Europe: The Challenge of the European Union. Journal of European Integration, Vol. 33, No. 2. 117-138. DOI: https://doi.org/10.1080/0703 6337.2011.543522

Diez, Thomas - Whitman, Richard G. (2002): Analysing European Integration. Reflecting on the English School - Scenarios for an Encounter. Journal of Common Market Studies, Vol. 40, No. 1. 43-67. DOI: https://doi.org/10.1111/1468-5965.00343

Dunne, Tim (2013): The English School. In Dunne, Tim - KuRki, Milja - SMith, Steve eds.: International Relations Theories - Discipline and Diversity. Oxford, Oxford University Press. 132-152. DOI: https://doi.org/10.1093/hepl/9780198707561.003.0007

EgEDy Gergely (2018): Az (észak)ír határ a Brexit folyamatában. Európai Tükör, 3. évf. 3. sz. 7-20.

Garben, Sacha (2011): EU Higher Education Law - The Bologna Process and Harmonization by Stealth. Zuidpoolsingel, Kluwer Law International.

Garben, Sacha (2017): Competence Creep Revisited. Journal of Common Market Studies, Vol. 57, No. 2. 205-222. DOI: https://doi.org/10.1111/jcms.12643

GARben, Sacha - Govaere, Inge (2017): The Division of Competences between the EU and the Member States: Reflections on the Past, the Present and the Future. In GARBEN, Sacha - GOVAERE, Inge eds.: The Division of Competences between the EU and the Member States - Reflections on the Past, the Present and the Future. Oregon, Hart Publishing. 3-18. DOI: https://doi.org/10.5040/9781509913503.ch-001

Gatti, Mauro (2017): Art. 50. TEU: A Well-Designed Secession Clause. European Papers, Vol. 2, No. 1. 159-181. DOI: https://doi.org/10.15166/2499-8249/149

HoffMeIsTER, Frank (2015): The European Union as an International Trade Negotiator. In Koops, JoachimA. - MACAJ, Gjovalin eds.: The European Unionas a DiplomaticActor. New York, Palgrave Macmillan. 138-154. DOI: https://doi.org/10.1057/9781137356857_9

JACKSON, Patrick Thaddeus (2011): The Conduct of Inquiry in International Relations: Philosophy of Science and Its Implications for the Study of World Politics. New York, Routledge. DOI: https://doi.org/10.4324/9781315731360

JELLINEK, Georg (1906): Verfassungsänderung und Verfassungswandlung: Eine staatsrechtlich-politische Abhandlung. Berlin, Häring.

Kuijper, Pieter Jan - Wouters, Jan - Hoffmeister, Frank - De BAere, Geert - RamoPOULOS, Thomas (2015): The Law of EU External Relations - Cases, Materials and Commentary on the EU as an International Legal Actor. Oxford, Oxford University Press.

KNudsen, Tony B. (2019): Fundamental Institutions and International Organizations: Theorizing Continuity and Change. In: KNudsen, Tony B. - NAVARI, Cornelia eds.: International Organization in the Anarchical Society. New York, Palgrave Macmillan. 23-50. DOI: https//doi.org/10.1007/978-3-319-71622-0_2

Konstantinides, Theodore (2009): Division of powers in European Union Law. The delimitation internal competence between the EU and the Member States. New York, Wolters Kluwer.

Louis, Jean-Victor (2006): Le droit de retrait de l'Union européenne. Cahiers de Droit Européen, Vol. 42, No. 3-4. 293-314.

Európai Tükör 2020/1. 
MARKS, Susan (2003): The Riddle of All Constitutions: International Law, Democracy and the Critique of Ideology. Oxford, Oxford University Press. DOI: https://doi.org/10.1093/ acprof:oso/9780199264131.001.0001

NAVARI, Cornelia - Knudsen, Tony B. (2019): Introduction: A New Approach to International Organization. In KNudsen, Tony B. - NAVARI, Cornelia eds.: International Organization in the Anarchical Society. New York, Palgrave Macmillan. 1-20. DOI: https://doi.org/10.1007/978-3-319-71622-0_1

Odermatt, Jed (2018): Unidentified Legal Object: Conceptualising the European Union in International Law. Connecticut Journal of International Law, Vol. 33, No. 2. 215-247. DOI: https://doi.org/10.2139/ssrn.3167220

Prieger Adrienn - Klemm Dávid (2019): A Brexit eddigi folyamata. Európai Jog, 19. évf. 1. sz. 12-22.

RAmalho, Ana (2011): The European Union and ACTA - or Making Omelettes Without Eggs (Again). International Review of Intellectual Property and Competetition Law, Vol. 42, No. 1. 97-101.

SAMPSON, Thomas (2017): Brexit: The Economics of International Disintegration. Journal of Economic Perspectives, Vol. 31, No. 4. 163-184. DOI: https://doi.org/10.1257/ jep.31.4.163

Schermers, Henry G. - BLOKKeR, Niels M. (2011): International Institutional Law - Unity within Diversity. Leiden, Martinus Nijhoff.

SchÜтze, Robert (2012): European Constitutional Law. Cambridge, Cambridge University Press. DOI: https://doi.org/10.1017/CBO9781139031769

SINCLAIR, Guy Fiti (2017): To Reform the World - International Organizations and the Making of Modern States. Oxford, Oxford University Press. DOI: https://doi.org/10.1093/ acprof:oso/9780198757962.001.0001

Sterling-Folker, Jennifer (2013): Neoliberalism. In Dunne, Tim - KuRki, Milja SMITH, Steve eds.: International Relations Theories - Discipline and Diversity. Oxford, Oxford University Press. 114-131. DOI: https://doi.org/10.1093/hepl/9780 198707561.001.0001

WENDT, Alexander - DuVALL, Raymond (1989): Institutions and International Order. In Czempiel, Ernst-Otto ed.: Global Changes and Theoretical Challenges: Approaches to World Politics for the 1990s. Lexington, Lexington Books. 51-73.

ZIEGLER, Katja (2011): International Law and EU Law: Between Asymmetric Constitutionalism and Fragmentation. In ORAKHELASHVILI, Alexander ed.: Research Handbook on the Theory and History of International Law. Chettenham, Edward Elgar. 268-327.

\section{Internetes források}

Európai Bizottság (2011): Vademecum on the External Action of the European Union. Elérhető: https://ec.europa.eu/transparency/regdoc/rep/2/2011/EN/SEC-2011-8811-EN-MAIN-PART-2.PDF (A letöltés dátuma: 2020. 04. 24.) 
Európai Bizottság (2018): Megállapodás nélküli brexit: az Európai Tanács (5. cikk) júniusi ülése előtt az Európai Bizottság mérleget von a felkészülésről. Elérhető: https://ec.europa.eu/commission/presscorner/detail/hu/IP_19_2951 (A letöltés dátuma: 2020. 03. 15.)

Európai Bizottság (2020): Recommendation for a Council Decision authorising the opening of negotiations for a new partnership with the United Kingdom of Great Britain and Northern Ireland. $\operatorname{COM(2020)~} 35$ final. Elérhető: https://eur-lex.europa.eu/legal-content/EN/TXT/?uri=CELEX\%3A52020PC0035 (A letöltés dátuma: 2020. 04. 24.)

GraY, Andrew (2019): Article 50 Author Lord Kerr: I didn't have UK in mind. Politico. Elérhető: www.politico.eu/article/brexit-article-50-lord-kerr-john-kerr/ (A letöltés dátuma: 2019. 05. 10.)

Kengyel Ákos (2010): Az Európai Unió külkapcsolati rendszere és világgazdasági pozíciói. BCE Világgazdasági tanszék. Elérhető: http://unipub.lib.uni-corvinus.hu/582/1/ Kengyel_wp2012c.pdf (A letöltés dátuma: 2020. 03. 15.)

KLEIN, Eckhart (2018): Self-Contained Regime, Max Planck Encyclopedia of Public International Law. Elérhető: https://opil.ouplaw.com/view/10.1093/law:epil/9780199231690/ law-9780199231690-e1467?prd=EPIL (A letöltés dátuma: 2019. 10. 31.)

PEers, Steve (2019): Analysis 5 of the revised Brexit withdrawal agreement: the political declaration on the EU/UK future relationship. Elérhető: http://eulawanalysis.blogspot. com/2019/10/analysis-5-of-revised-brexit-withdrawal.html. (A letöltés dátuma: 2020. 03. 15.)

Peers, Steve (2020): Negotiating the Future Relationship between the UK and EU: the EU Negotiating Mandate. EU Law Analysis. Elérhető: http://eulawanalysis.blogspot.com/2020/02/negotiating-future-relationship-between_26.html (A letöltés dátuma: 2020. 03. 15.)

Scheele, Ricarda (2013): Is the English School Just Another Paradigm in IR? E-International Relations Students. Elérhető: www.e-ir.info/2013/10/24/is-the-english-school-just-another-paradigm-in-ir/ (A letöltés dátuma: 2020. 02. 08.)

WeAtherhill, Stephen (2018): Why the withdrawal notification under Article 50 TEU is not unilaterally revocable. EU Law Analysis. Elérhető: http://eulawanalysis.blogspot.com/2018/01/can-article-50-notice-of-withdrawal.html (A letöltés dátuma: 2020. 05. 05.)

Wolff, Guntram B. (2019): The implications of a no-deal Brexit: is the European Union prepared? Policy Contribution. Elérhető: www.bruegel.org/wp-content/uploads/2019/01/PC-2019-02-140119.pdf (A letöltés dátuma: 2020. 03. 15.)

\section{Jogi források}

Az Európai Parlament és a Tanács (EU) 2019/502 Rendelete (2019. március 25.) NagyBritannia és Észak-Írország Egyesült Királyságának az Unióból történő kilépésével összefüggésben az alapszintű légi összeköttetést biztosító közös szabályokról

A Bíróság 1/91. sz. Megállapodás-tervezet az Európai Gazdasági Térség létrehozásáról egyrészről a Közösség, másrészről az Európai Szabadkereskedelmi Társulás tagjai között kapcsán 1991. december 14-én hozott véleménye [ECLI:EU:C:1991:490] 
A Bíróság 1/94. sz. a Közösség hatásköre a szolgáltatásokról és a szellemi tulajdon oltalmáról szóló nemzetközi szerződések megkötése kapcsán hozott vélemény [ECLI:EU:C:1994:384] 108. pontja

A Bíróság 2/15. sz. az Európai Unió és a Szingapúri Köztársaság közötti szabadkereskedelmi megállapodás kapcsán hozott vélemény [ECLI:EU:C:2017:376] 103. pontja.

A Bíróság 2/91. sz. a Nemzetközi Munkaügyi Szervezet 170. sz. egyezménye kapcsán hozott vélemény [ECLI:EU:C:1993:106] 36. pontja

A Bíróság C-26/62. sz. Van Gend en Loos kontra Administratie der Belastingen ügyben 1963. február 5-én hozott ítélete [ECLI:EU:C:1963:1]

A Bíróság (teljes ülés) 2/13. sz. az Európai Uniónak az emberi jogok és alapvető szabadságok védelméről szóló európai egyezményhez történő csatlakozása kapcsán 2014. december 18-án hozott vélemény [ECLI:EU:C:2014:2454] 157. és 158. pontja

A Bíróság (teljes ülés) C-370/12. sz. Thomas Pringle kontra Government of Ireland és társai ügyben 2012. november 27-én hozott ítélete [ECLI:EU:C:2012:756]

Az EUB (teljes ülés) C-621/18. sz. Wightman és társai ügyben 2018. december 10-én hozott ítélete [ECLI:EU:C:2018:999]

Az Európai Unió Múködéséről szóló Szerződés [HL C 326., 2012.10.26., 47-390. o. (GA)]

Az Európai Unióról szóló Szerződés [HL C 326., 2012. 10. 26., 13-390. o. (GA)]

Directives for the negotiation of a new partnership with the United Kingdom of Great Britain and Northern Ireland [5870/20 ADD 1 REV 3]

Értesítés az egyrészről Kanada, másrészről az Európai Unió és tagállamai közötti átfogó gazdasági és kereskedelmi megállapodás (CETA) ideiglenes alkalmazásáról (2017). OJ L 238, 16.9.2017. 9-9. [HL L 85I., 2019.3.27., 49-59. o.]

Nagy-Britannia és Észak-Írország Egyesült Királyságának az Európai Unióból és az Európai Atomenergia-közösségből történő kilépéséről szóló megállapodása [HL L 29., 2020.1.31., 7-187. o.]

Political Declaration Setting Out the Framework for the Future Relationship between the European Union and the United Kingdom [2020/C 34/01] 